\title{
Differential responses to genotoxic agents between induced pluripotent stem cells and tumor cell lines
}

\author{
Yinghua $\mathrm{Lu}^{1,2}$, Dazhong $\mathrm{Xu}^{2}$, Jing Zhou ${ }^{2}$, Yupo $\mathrm{Ma}^{3}$, Yongping Jiang ${ }^{4}$, Wenxian Zeng ${ }^{1 *}$ and Wei Dai ${ }^{2^{*}}$
}

\begin{abstract}
Given potential values of induced pluripotent stem (iPS) cells in basic biomedical research and regenerative medicine, it is important to understand how these cells regulate their genome stability in response to environmental toxins and carcinogens. The present study characterized the effect of $\mathrm{Cr}(\mathrm{VI})$, a well-known genotoxic agent and environmental carcinogen, on major molecular components of DNA damage response pathways in human iPS cells. We compared the effect of $\mathrm{Cr}(\mathrm{VI})$ on human iPS cells with two established cell lines, Tera-1 (teratoma origin) and BEAS-2B (lung epithelial origin). We also studied the effect of hydrogen peroxide and doxorubicin on modulating DNA damage responses in these cell types. We demonstrated that ATM and p53 phosphorylation is differentially regulated in human iPS cells compared with Tera-1 and BEAS-2B cells after exposure to various genotoxic agents. Moreover, we observed that inhibition of CK2, but not p38, promotes phosphorylation of $\mathrm{p} 53^{\mathrm{S} 392}$ in iPS cells. Combined, our data reveal some unique features of DNA damage responses in human iPS cells.
\end{abstract}

Keywords: iPS cells, Genotoxic stress, DNA damage, Chromium, Phosphorylation, P53

\section{Introduction}

Induced pluripotent stem (iPS) cells are derived from somatic cells through genetic re-programming. Simultaneous ectopic expression of key transcription factors such as OCT4, SOX2, KLF4 and c-MYC can reprogram human somatic cells to pluripotent stem cells capable of differentiation into a variety of cell types [1]. Human iPS cells thus represent a valuable resource for the development of in vitro models for human diseases and have great potentials in regenerative medicine [2]. Recent studies have shown that human iPS cells also offer a valuable alternative to human embryonic stem cells for drug development [3], as well as for in vitro expansion and differentiation into cells of the hematopoietic lineage $[4,5]$. It is well known that cells undergoing in vitro expansion are constantly exposed to a variety of environmental insults including genotoxic agents and oxidative stress. Given the great

\footnotetext{
*Correspondence: zengwnxian@hotmail.com; wei.dai@nyumc.org ${ }^{1}$ College of Animal Science and Technology, Northwest A\&F University, Yangling, Shaanxi, China

${ }^{2}$ Department of Environmental Medicine \& Pharmacology, New York University Langone Medical Center, 57 Old Forge Road, Tuxedo, NY, USA Full list of author information is available at the end of the article
}

potential of iPS cells, it is imperative to understand the characteristics of these cells, especially regarding their genomic stability after exposure to environmental genotoxic agents.

Chromium (VI) compounds are well established environmental carcinogens that produce genotoxic effects leading to human cancers [6-9]. Chromium (VI) generates reactive oxygen species (ROS) that induce DNA damage, which is thought to trigger DNA damage responses in somatic cells [6-8]. Although some studies have been carried out with an emphasis on toxic and carcinogenic effects of $\mathrm{Cr}(\mathrm{VI})$ compounds on somatic cells $[7,8]$, its effect on human iPS cells remains largely unknown. In fact, very limited studies have been conducted on DNA damage responses caused by genotoxic agents in either embryonic stem cells or iPS cells. $\mathrm{Cr}(\mathrm{VI})$ has been shown to inhibit differentiation of murine embryonic stem cells [10]. A strong DNA damage response induced by $\gamma$-irradiation has been demonstrated in human iPS cells [11]. Given the unique chromatin structure of iPS cells, it is likely these cells may respond to DNA damage differently after challenge with genotoxic agents including $\mathrm{Cr}(\mathrm{VI})$ compared with those cells of the somatic origin. 
The DNA damage response entails a series of signaling events including auto-phosphorylation of ATM and phosphorylation of histone H2AX and p53 [12,13]. Extensive research in the past has identified amino acid residues in these proteins that are characteristic of DNA damage responses [13-17]. They include $\mathrm{ATM}^{\mathrm{S} 1981}, \mathrm{p} 53^{\mathrm{S} 15}, \mathrm{p} 53^{\mathrm{S} 20}$, $\mathrm{p} 53^{\mathrm{S} 392}$, and $\mathrm{H} 2 \mathrm{AX}^{\mathrm{S} 139}$ [13-17]. In the current study, we evaluated the effect of $\mathrm{Cr}(\mathrm{VI})$ on expression and/or activation of several key molecular components mediating DNA damage responses in human iPS cells and compared it with those of transformed cells from the somatic origin (Tera-1 and BEAS-2B). As additional controls, we also exposed these cells to $\mathrm{H}_{2} \mathrm{O}_{2}$ and doxorubicin (Dox), two well studied genotoxic agents. We found that human iPS cells responded differently to $\mathrm{Cr}(\mathrm{VI})$ compared with Tera- 1 and BEAS-2B cells in terms of activation of DNA damage response pathway. In addition, we observed that iPS cells, Tera- 1 and BEAS-2B exhibited differential responses after $\mathrm{H}_{2} \mathrm{O}_{2}$ or Dox treatment. Our findings indicate that iPS cells have some unique features to $\mathrm{Cr}(\mathrm{VI})$ and other genotoxic agents that can be explored for potential drug developments.

\section{Experimental procedures}

\section{Cell lines and cell culture}

Human induced pluripotent stem cells were derived from human amniotic fluid-derived cells (hAFDCs) via retrovirusmediated expression of four transcription factors (OCT4/ SOX2/KLF4/C-MYC). Human iPS cells were cultured in 6$\mathrm{cm}$ tissue culture dishes coated with matrix (Invitrogen, USA) in a feeder-free culture conditions using Essential $8^{\mathrm{m}}$ medium. Human iPSCs grown on feeder-dependent culture conditions (Mitomycin C treated murine embryonic fibroblasts) were maintained in DMEM-F12 (Invitrogen, USA) medium which was supplemented with $20 \% \mathrm{KSR}, 10 \mathrm{ng} / \mathrm{mL}$ bFGF, $2 \mathrm{mM}$ GlutaMAX ${ }^{\mathrm{m}}$-I, $0.1 \mathrm{mM}$ MEM Non-Essential Amino Acids Solution, $1 \times \beta$-mercaptoethanol. Cells were passed every 5-6 days after trypsinization. Mitomycin C treated murine embryonic fibroblasts (MEFs) were prepared as feeder cells. Tera- 1 cells obtained from American Type Culture Collection (ATCC) were cultured in McCoy's 5A medium supplemented with $10 \%$ fetal bovine serum (FBS). BEAS-2B cells obtained from ATCC were cultured in DMEM supplemented with $10 \%$ FBS.

\section{Antibodies}

Antibodies to p53, NANOG and SOX2 (for flow cytometry) were purchased from Santa-Cruz Biotechnology. Antibodies to OCT4, SOX2 (for Western blot), ATM, phospho-ATM ${ }^{\mathrm{S} 1981}\left(\mathrm{p}-\mathrm{ATM}^{\mathrm{S} 1981}\right), \mathrm{p}-\mathrm{p} 53^{\mathrm{S} 15}, \mathrm{p}-\mathrm{p} 53^{\mathrm{S} 20}, \gamma$ H2AX, p-p53 ${ }^{\mathrm{S} 392}$, p-p38, p38, PARP-1, $\alpha$-tubulin, $\beta$-actin were purchased from Cell Signaling Technology.

\section{Fluorescence microscopy}

Human iPS cells were fixed in 4\% paraformaldehyde (PFA) and washed with PBS containing 5\% BSA and $0.4 \%$ Triton X-100. These cells were subsequently incubated with antibodies against OCT4 at $37^{\circ} \mathrm{C}$ for $1 \mathrm{~h}$ followed by washing three times with PBS with Tween. Cells were then incubated with a secondary antibody conjugated with Alexa Fluor 555 at $37^{\circ} \mathrm{C}$ for $45 \mathrm{~min}$ followed by wash three times with PBS with Tween. After brief staining with Hoechst, cells were examined under a fluorescence microscope.

\section{Flow cytometry analysis}

Human iPS cells were disaggregated by 0.5 mM EDTA, washed with PBS, and then treated with $4 \%$ PFA and $0.4 \%$ Triton X-100 for $30 \mathrm{~min}$. After wash twice with cold PBS containing $0.5 \%$ fetal bovine serum, cells were incubated with an anti-human NANOG or SOX2 antibody for $30 \mathrm{~min}$ at $4^{\circ} \mathrm{C}$. Subsequently, these cells were stained with a second antibody IgG conjugated with Alexa Fluor555 for 30 min. Isotype control IgG was used as control. The fluorescence-labeled cells were analyzed with flow cytometry.

\section{Differentiation of iPS cells}

Human iPS cells were maintained in Essential $8^{\mathrm{TM}}$ medium (Life Technologies). OP-9 cells were cultured in the MEM $\alpha$ medium containing 20\% FCS. The iPS cells were induced to differentiate into embryonic stem cell sacs (ES-sacs) as described [18]. Briefly, the small clumps of human iPS cells were transferred onto OP-9 cells and cultured in a differentiation medium (IMDM supplemented with $10 \mu \mathrm{l} / \mathrm{ml}$ ITS $100 \times$ stock solution, $2 \mathrm{mM}$ L-glutamine, $0.45 \mu \mathrm{M}$ MTG, $50 \mu \mathrm{g} / \mathrm{ml}$ ascorbic acid, 15\% FBS and $20 \mathrm{ng} / \mathrm{ml}$ recombinant human VEGF), which was refreshed every 3 days. On days 14 to 15 of culture, ES-sacs emerged. Representative images of ES-sacs were captured under microscope. Human iPS cells were induced to differentiate toward the neural lineage was carried out using STEMdiff ${ }^{\text {si }}$ Neural Induction Medium according to the manufacturer's protocol (Stem Cell Technologies).

\section{Western blot}

Human iPS cells treated with appropriate chemicals for various times were washed twice with ice-cold PBS and lysed in $310 \mu \mathrm{L}$ RIPA buffer supplemented with protease and phosphatase inhibitors. Cell lysates were centrifuged by at $12,000 \mathrm{~g}$ for $15 \mathrm{~min}$ at $4{ }^{\circ} \mathrm{C}$. Equal amounts of cell lysates $(20 \mu \mathrm{g})$ were mixed with $6 \times$ SDS loading buffer, heated at $100^{\circ} \mathrm{C}$ for $5 \mathrm{~min}$, and analyzed by SDS-PAGE followed by Western blotting. 


\section{Results}

\section{Characterization of human iPS cells}

Human iPS cells were obtained from amniotic fluid-derived cells after ectopic expression of four stem cell transcription factors (OCT4, SOX2, KLF4 and c-MYC) via the retroviral expression system. Microscopic examinations revealed that these cells exhibited a stem cell-like morphology and expressed abundant OCT4 and SOX2 (Figure 1A and B). Further characterization via flow cytometry indicated that these cells were also highly positive for NANOG and SOX2. We further examined these for their capacity for differentiation. Through incubation in a medium optimal for differentiation, we observed that these cells were capable of differentiating into cells with morphologic characteristics of neural cells or embryonic stem cell sacs (ES sacs) (Figure 1D). Combined, these results indicate that iPS cells under study bear essential characteristics of stem cells.

\section{Dose-dependent responses of human iPS and Tera-1 cells to $\mathrm{Cr}(\mathrm{VI})$}

To study whether iPS cells were capable of responding to $\mathrm{Cr}(\mathrm{VI})$, we treated iPS cells, as well as Tera- 1 cells as control, with the compound at various concentrations for $24 \mathrm{~h}$. Western blot analysis revealed that p53 protein level displayed a slight increase after treatment with $\mathrm{Cr}(\mathrm{VI})$ in iPS cells (Figure 2A). We did not detect any significant induction of $\mathrm{p}-\mathrm{ATM}^{\mathrm{S} 1981}$ (p-ATM thereafter) signals in human iPS cells (Figure 2A). In Tera-1 cells, p-ATM was induced by $10 \mu \mathrm{M} \mathrm{Cr}(\mathrm{VI})$, peaking at $25 \mu \mathrm{M}$ (Figure $2 \mathrm{~B}$ ). In iPS cells, a relatively high basal level of $\gamma \mathrm{H} 2 \mathrm{AX}$ was present in untreated cells, which was not further increased after $\mathrm{Cr}$ (IV) treatment. In contrast, no basal level of $\gamma \mathrm{H} 2 \mathrm{AX}$ was detectable in Tera-1 cells and it was strongly induced by $\mathrm{Cr}$ (VI) at concentrations higher than $25 \mu \mathrm{M}$, which coincided with ATM phosphorylation/activation (Figure 2B). Phosphorylation of p53 on both S15 and S20 also exhibited a differential response to $\mathrm{Cr}(\mathrm{VI})$ treatment between iPS and Tera- 1 cells. In iPS cells, p53 phosphorylation on S20 was not easily detectable whereas its phosphorylation on S15 was somewhat inducible. On the other hand, both S20 and S15 phosporylation in Tera-1 cells was strongly induced and S20 phosphorylation exhibited a dose-dependent increase after $\mathrm{Cr}(\mathrm{VI})$ treatment (Figure 2). The pattern of phosphorylation closely followed that of p-ATM signals. Combined, these data suggests that iPS cells are more resistant to $\mathrm{Cr}(\mathrm{VI})$-induced DNA damage or that the DNA damage response pathway is suppressed in iPS cells. Intriguingly, expression of OCT4 in Tera-1 cells, but not in iPS cells, was suppressed by $\mathrm{Cr}(\mathrm{VI})$ (Figure $2 \mathrm{~A}$ and $\mathrm{B}$ ).

\section{Time-dependent response of human iPS, Tera-1, and BEAS-2B cells to $\mathrm{Cr}(\mathrm{VI})$}

We next determined the kinetics of phosphorylation/ activation of various components in the DNA damage- response pathway. We treated iPS and Tera-1 cells with $10 \mu \mathrm{M} \mathrm{Cr}(\mathrm{VI})$ as this concentration elicited a minimal response of apoptosis while it activated ATM and p53 phosphorylation in Tera-1 cells (Figure 2B). We also treated BEAS-2B cells with $\mathrm{Cr}(\mathrm{VI})$ as an additional somatic cell control. In these experiments, iPS cells were cultured under feeder-free cultural conditions as opposed to the feeder-dependent condition in the previous studies so as to eliminate any potential interference of signals from the feeder cells.

There was a clear time-dependent increase in the p53 protein level in iPS cells and Tera-1 cells after $\mathrm{Cr}(\mathrm{VI})$ treatment (Figure $3 \mathrm{~A}$ and $\mathrm{B})$. A longer $\mathrm{Cr}(\mathrm{VI})$ treatment caused a decline of p53 in iPS cells. Interestingly, the p53 level in BEAS-2B was not significantly modulated during the treatment period (Figure $3 \mathrm{C}$ ). The p-ATM level in iPS cells exhibited a biphasic pattern of induction after $\mathrm{Cr}(\mathrm{VI})$ treatment. It was slightly induced at about $1 \mathrm{~h}$ after treatment and then declined below the basal level until it increased again after cells were treated for more than $24 \mathrm{~h}$ (Figure 3A). The $\gamma \mathrm{H} 2 \mathrm{AX}$ signal was closely associated with the second phase of ATM phosphorylation in iPS cells. The p-ATM level in Tera-1 cells was only significantly elevated $24 \mathrm{~h}$ post $\mathrm{Cr}(\mathrm{VI})$ treatment, which was also correlated with the $\gamma \mathrm{H} 2 \mathrm{AX}$ signal (Figure 3B). Despite the non-detectable level of p-ATM in BEAS-2B cells, the $\gamma \mathrm{H} 2 \mathrm{AX}$ signal was increased in a manner similar to that in either iPS or Tera- 1 cells.

Phosphorylation of p53 in three cells types was quite different. While the level of $\mathrm{p}-\mathrm{p} 53^{\mathrm{S} 15}$ in iPS cells did not show significant changes over time after $\mathrm{Cr}(\mathrm{VI})$ treatment, it was strongly induced in Tera- 1 and BEAS-2B cells and its induction was time-dependent (Figure 3A-C). However, the $\mathrm{p}-\mathrm{p} 53^{\mathrm{S} 15}$ signal increased beyond $48 \mathrm{~h}$ in Tera- 1 cells whereas it peaked at about $4 \mathrm{~h}$ post $\mathrm{Cr}(\mathrm{VI})$ treatment. In both iPS and Tera-1 cells, the level of $\mathrm{p}-\mathrm{p} 53^{\mathrm{S} 20}$ was undetectable before and after $\mathrm{Cr}(\mathrm{VI})$ treatments (Figure 3A and $\mathrm{B})$. In contrast, $\mathrm{p}-\mathrm{p} 53^{\mathrm{S} 20}$ signal exhibited a timedependent increase post treatment in BEAS-2B cells (Figure $3 \mathrm{C}$ ). The phosphorylation level of $\mathrm{p}-\mathrm{p} 53^{\mathrm{S} 392}$, another important phosphorylation site in response to genotoxic stress [13], was distinctive among these three cell types. There were no detectable basal levels of $\mathrm{p}$ $\mathrm{p} 53^{\mathrm{S} 392}$ in iPS cells and Tera-1 cells (Figure $3 \mathrm{~A}$ and B). However, it was inducible in Tera- 1 cells after $\mathrm{Cr}(\mathrm{VI})$ treatment. There was a high basal level of $\mathrm{p}-\mathrm{p} 53^{\mathrm{S} 392}$ in BEAS-2B cells, which could not be further induced by exposure to $\mathrm{Cr}(\mathrm{VI})$.

Time-dependent response of human iPS cells, Tera-1, and BEAS-2B cells to $\mathrm{H}_{2} \mathrm{O}_{2}$

One of the main mechanisms for $\mathrm{Cr}(\mathrm{VI})$-induced DNA damage responses is the generation of reactive oxygen species (ROS) [6-9]. We next examined the effect of $\mathrm{H}_{2} \mathrm{O}_{2}$ on 

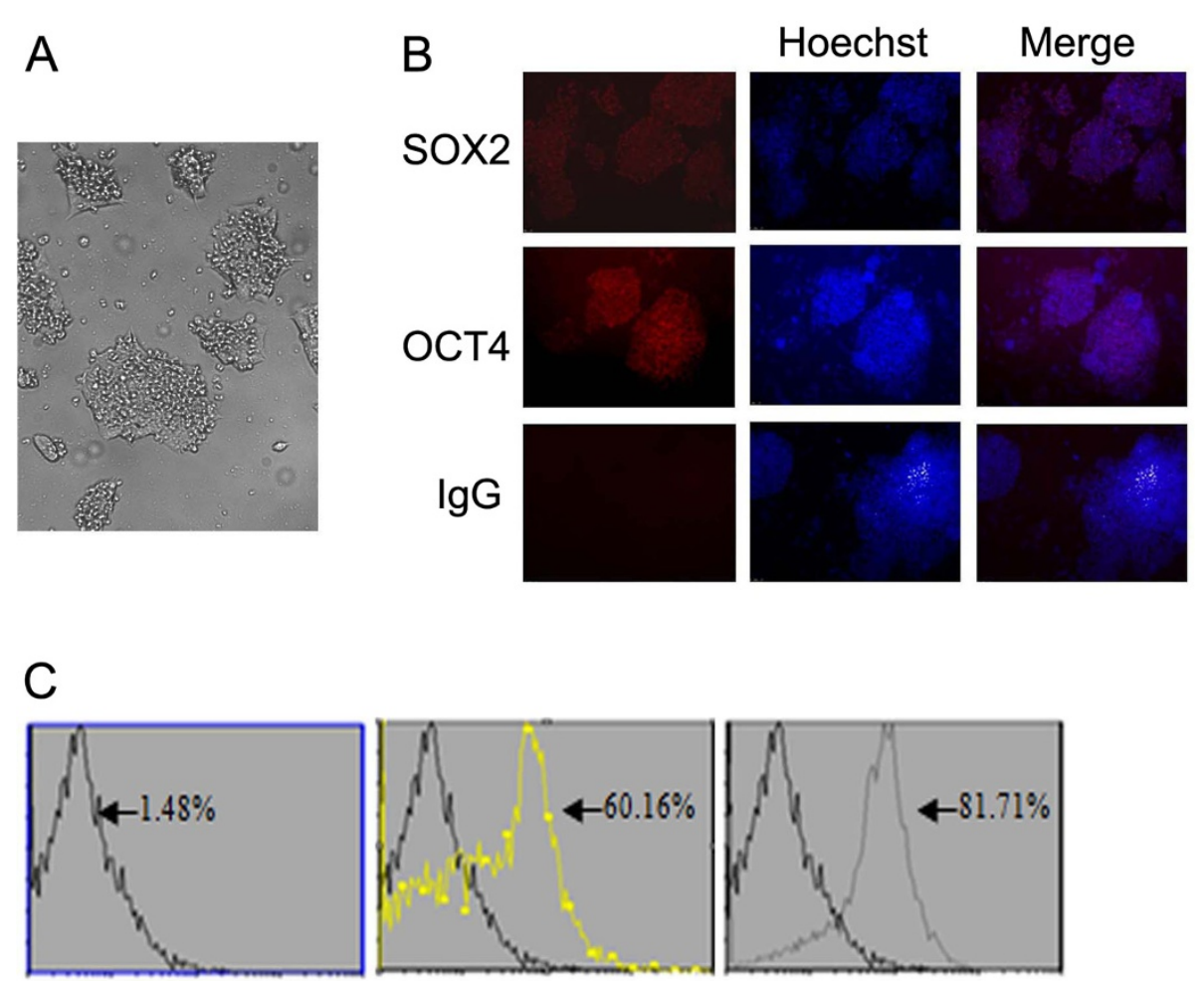

$\lg G$
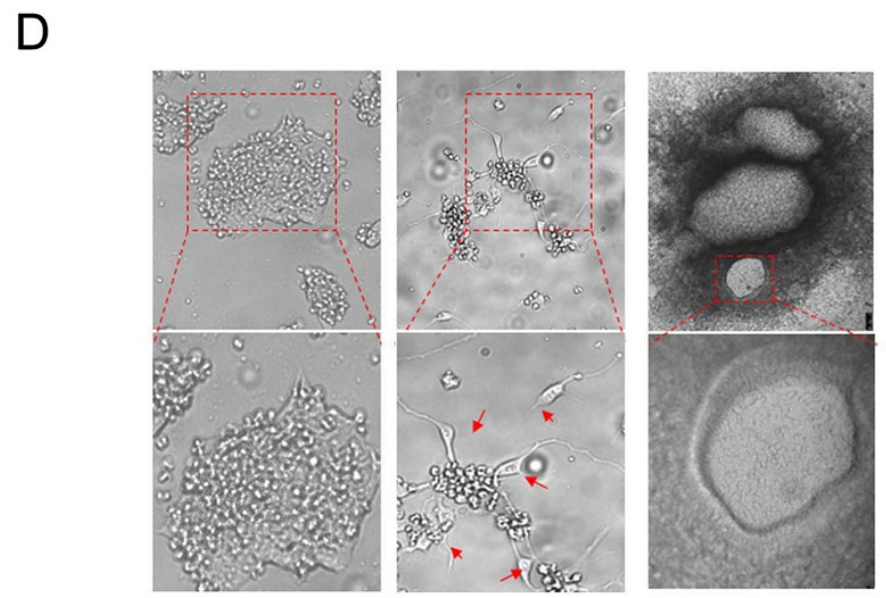

\section{iPS Cells Differentiated EB-Sacs}

Figure 1 Characterization of iPS cells. (A) General morphology of iPS cells under study. (B) Human iPS cells were cultured on chamber slides, fixed and stained with either a control IgG or antibodies to SOX2 and OCT4. DNA was stained with Hoechst. Representative images are shown. (C) Human IPS cells were fixed and stained with either lgG or antibodies to NANOG and SOX2. Cells were then processed for analysis by flow cytometry. Experiments were repeated for at least three times. (D) Human iPS cells were cultured in a differentiation medium as described in Experimental procedures. Representative images of embryonic stem cell sacs (ES-sacs) and neural differentiation are shown.

the activation of key components of DNA damage responses in iPS, Tera-1 and BEAS-2B cells. We observed that different cell types responded to $\mathrm{H}_{2} \mathrm{O}_{2}$ in a manner similar to that of $\mathrm{Cr}(\mathrm{VI})$ with regard to p53 induction and activation (Figure 4). The total p53 level was slightly induced in iPS cells and was below the pretreatment level after $24 \mathrm{~h}$ treatment (Figure 4A). Whereas p53 was gradually induced in Tera-1 cells it was not significantly changed in BEAS-2B cells (Figure 4B and C). The p-ATM level in iPS cells treated with $\mathrm{H}_{2} \mathrm{O}_{2}$ displayed a biophasic pattern similar to that of $\mathrm{Cr}(\mathrm{VI})$ treatment (Figure 4A). In Tera- 1 cells, however, p-ATM was induced most strongly 

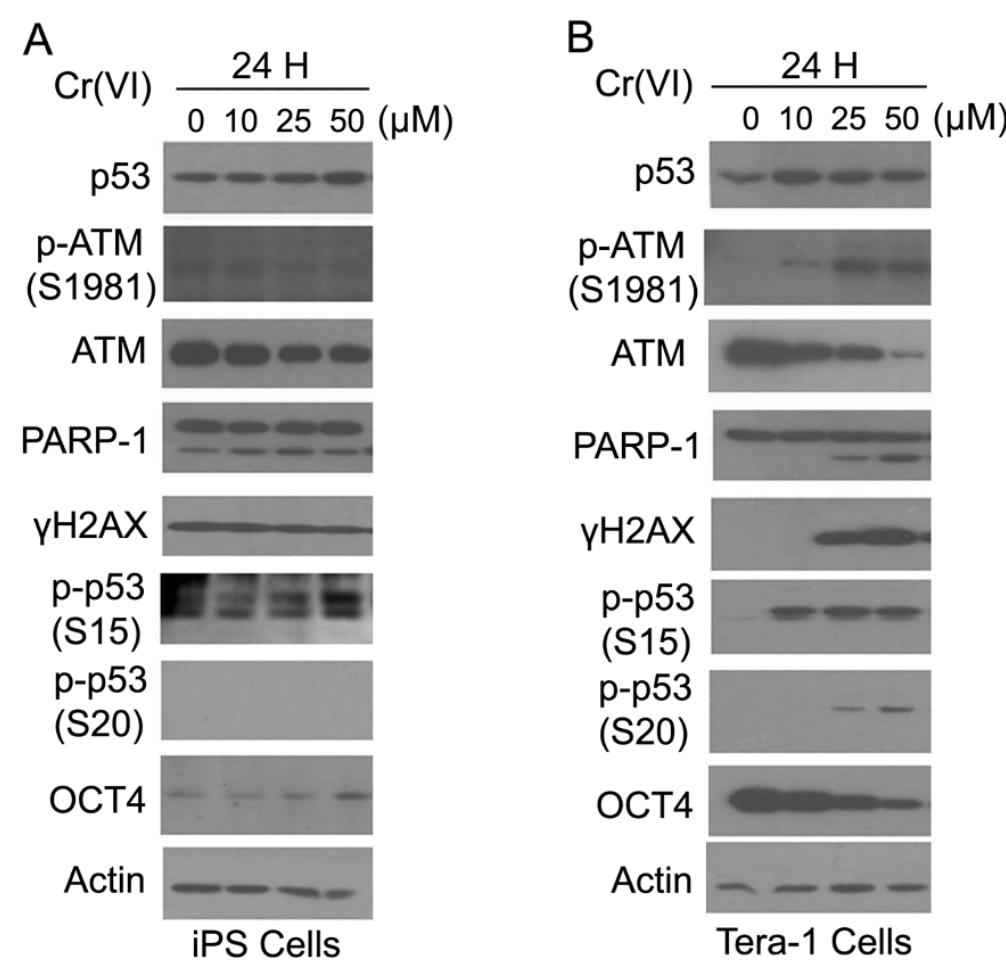

Figure 2 Dose-dependent responses of human iPS and Tera-1 cells to $\operatorname{Cr}(\mathrm{VI})$. (A) Human iPS cells were cultured with feeder cells as described in Experimental procedures and treated with $\mathrm{Cr}(\mathrm{VI})$ at various concentrations for $24 \mathrm{~h}$. Whole cell lysates were then collected for Western blot analyses with various antibodies as indicated. (B) Tera-1 cells were cultured as indicated in Experimental procedures and treated with $\mathrm{Cr}(\mathrm{Vl})$ for $24 \mathrm{~h}$. Equal amounts of cell lysates were blotted with antibodies as indicated.

at about $1 \mathrm{~h}$ of treatment (Figure $4 \mathrm{~B}$ ). This pattern was different from that of $\mathrm{Cr}(\mathrm{VI})$ treated Tera-1 cells, which only showed significant elevation of p-ATM at $24 \mathrm{~h}$ and $48 \mathrm{~h}$ time points (Figure 3B). In BEAS-2B cells, the p-ATM level was only slightly elevated over time after $\mathrm{H}_{2} \mathrm{O}_{2}$ treatment (Figure $4 \mathrm{C}$ ), which is similar to the response to $\mathrm{Cr}(\mathrm{VI})$ (Figure 3C). The level of $\gamma \mathrm{H} 2 \mathrm{AX}$ in three cell types responded very differently to $\mathrm{H}_{2} \mathrm{O}_{2}$ compared with that in cells treated with $\mathrm{Cr}(\mathrm{VI})$. In iPS cells, it was strongly induced and the induction was time-dependent (Figure 4A). Surprisingly, we did not observe any induction of $\gamma \mathrm{H} 2 \mathrm{AX}$ in Tera-1 and BEASE-2B cells after $\mathrm{H}_{2} \mathrm{O}_{2}$ treatment (Figure $4 \mathrm{~B}$ and $\mathrm{C}$ ). This is in sharp contrast with the responses of these cells to $\mathrm{Cr}(\mathrm{VI})$, which was strongly induced at $48 \mathrm{~h}$ after $\mathrm{Cr}(\mathrm{VI})$ treatments (Figure $4 \mathrm{~B}$ and $\mathrm{C}$ ). In iPS cells, the level of $\mathrm{p}-\mathrm{p} 53^{\mathrm{S} 15}$ was significantly increased in a time-dependent fashion, peaking at $8 \mathrm{~h}$ of treatment (Figure 4A). Interestingly, $\mathrm{H}_{2} \mathrm{O}_{2}$ did not significantly induce $\mathrm{p}-\mathrm{p} 53^{\mathrm{S} 15}$ in either Tera-1 or BEAS-2B cells. Therefore, $\mathrm{H}_{2} \mathrm{O}_{2}$ behaves differently in induction of p-p53 ${ }^{\mathrm{S} 15}$ compared with that of $\mathrm{Cr}(\mathrm{VI})$. Similar to $\mathrm{Cr}(\mathrm{VI}), \mathrm{H}_{2} \mathrm{O}_{2}$ did not induced any p-p53 ${ }^{\mathrm{S} 20}$ (compare Figures $3 \mathrm{~A}$ and $4 \mathrm{~A}$ ). However, the level of $\mathrm{p}-\mathrm{p} 53^{\mathrm{S} 20}$ in Tera- 1 cells was elevated in response to $\mathrm{H}_{2} \mathrm{O}_{2}$ treatments (Figure 4B). This was in contrast to the response to $\mathrm{Cr}(\mathrm{VI})$, which showed no increase (Figure 3B). In Tera- 1 cells, $\mathrm{p}-\mathrm{p} 53^{\mathrm{S} 392}$ levels were rapidly induced by $\mathrm{H}_{2} \mathrm{O}_{2}$ and remained elevated throughout the time course, which was different from the timedependent increase shown in $\mathrm{Cr}(\mathrm{VI})$ treatments (Figure 3B with Figure 4B). In BEAS-2B cells, however, the kinetics of p-p53 ${ }^{\mathrm{S} 392}$ level after $\mathrm{H}_{2} \mathrm{O}_{2}$ treatment was similar to that of $\mathrm{Cr}(\mathrm{VI})$ (Figure 3C with Figure 4C).

\section{Time-dependent response of human iPS cells, Tera-1, and} BEAS-2B cells to Dox

Given that doxorubicin (Dox) is capable of inducing double strand breaks $[19,20]$, we further analyzed DNA damage responses in three different cell types after treatment with this chemical compound. Again, we observed that general patterns of total p53 levels in response to Dox were similar to those induced by either $\mathrm{Cr}(\mathrm{VI})$ or $\mathrm{H}_{2} \mathrm{O}_{2}$. A steady increase of p53 was observed in both iPS and Tera-1 cells whereas it was largely unchanged in BEAS-2B cells (Figure 5). In contrast to $\mathrm{Cr}(\mathrm{VI})$ and $\mathrm{H}_{2} \mathrm{O}_{2}$, Dox induced p-ATM in a time-dependent fashion in iPS cells (Figure 5A). The level of p-ATM in Tera-1 and BEAS-2B cells after Dox treatment was similar to that of $\mathrm{H}_{2} \mathrm{O}_{2}$ (Figure 5B). It rapidly increased, peaking at about $4 \mathrm{~h}$ post treatment followed by a gradual decline to the pretreatment level (Figure 5B and C). Gamma 

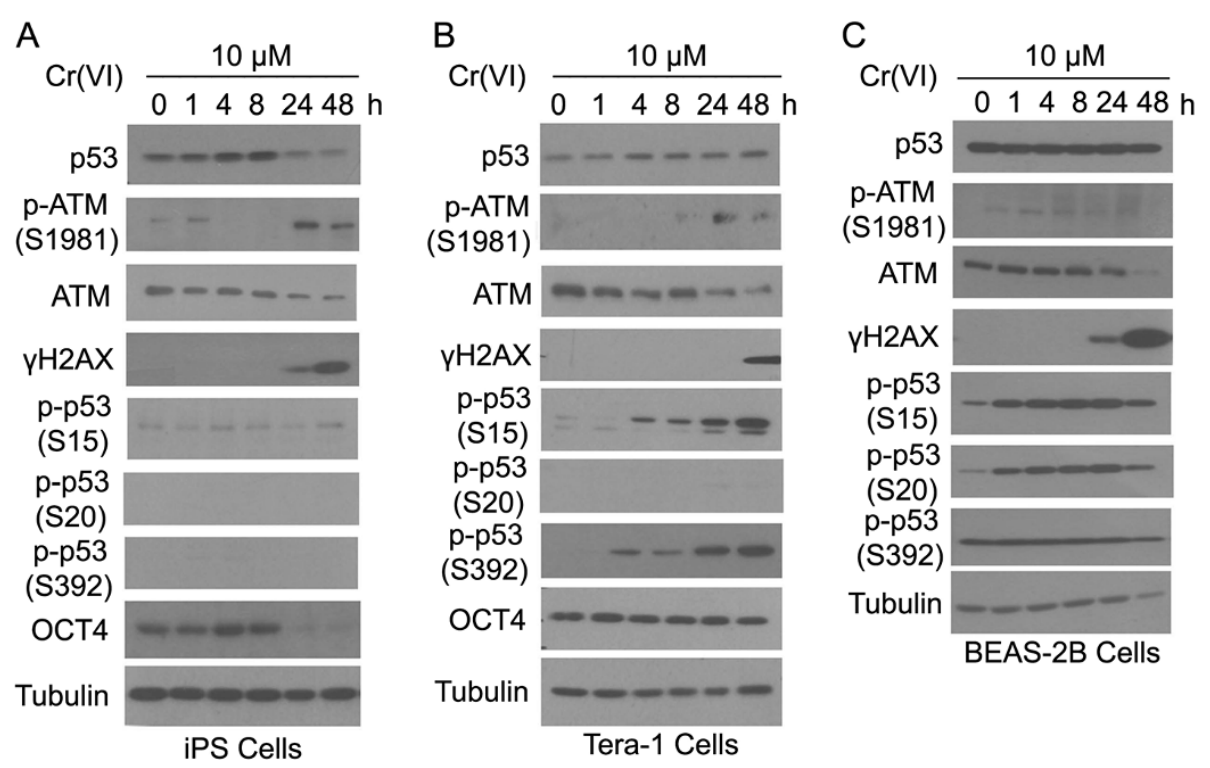

Figure 3 Time-dependent responses of human iPS cells, Tera-1, and BEAS2B cells to $\mathrm{Cr}(\mathrm{VI})$. (A) Human iPS cells were cultured under the feeder-free condition as described in Experimental procedures and treated with $10 \mu \mathrm{M} C r(\mathrm{VI})$ for various times as indicated. The whole cell lysates were collected and equal amounts of cell lysates were blotted with various antibodies as indicated. (B) Tera-1 cells were treated and analyzed as shown in A. (C) BEAS2B cells were treated and analyzed as shown in $\mathbf{A}$.

H2AX signals in iPS and BEAS-2B cells were strongly induced after extended treatment with Dox (Figure 5A and C). Intriguingly, $\gamma \mathrm{H} 2 \mathrm{AX}$ signals in Tera-1 cells were transiently induced at about $4 \mathrm{~h}$ post treatment (Figure 5B). Different from $\mathrm{Cr}(\mathrm{VI})$, Dox was capable of inducing p-p53 $3^{\mathrm{S} 15}$ in iPS cells (Figure 5A). On the other hand, Dox induced $\mathrm{p}-\mathrm{p} 53^{\mathrm{S} 15}$ only after $24 \mathrm{~h}$ of treatment (Figure $5 \mathrm{~B}$ ), which is very different from that in cells treated with $\mathrm{Cr}(\mathrm{VI})$ or $\mathrm{H}_{2} \mathrm{O}_{2}$. Phosphorylation of p53 on S20 was only strongly induced by Dox in BEAS-2B cells whereas phosphorylation on S392 was induced in both iPS and Tera-1 cells, but not in BEAS-2B cells. Table 1 summarizes the time-dependent responses of the three cell lines to three different types of genotoxic agents.

\section{Roles of $\mathrm{p} 38$ and CK2 on $\mathrm{p} 53^{\mathrm{S392}}$ phosphorylation}

The striking difference in $\mathrm{p} 53^{\mathrm{S} 392}$ phosphorylation between three cell types in response to different stimuli prompted us to further explore on the potential kinases that phosphorylate this residue in these cells. Previous studies have shown that the p38 MAP kinase and casein kinase 2 (CK2) are the main kinases that phosphorylate $\mathrm{p} 53^{\mathrm{S} 392}$ [21-23]. We examined whether these two kinases are responsible for the observed differential phosphorylation of this residue. As shown in Figure 6A (lanes 1-8), p38 was not activated by these genotoxic agents as indicated by the p-p38 level. The specific p38 inhibitor SB203580 had no effect on the phosphorylation of p53 3392 induced by $\mathrm{H}_{2} \mathrm{O}_{2}$ or Dox in iPS or Tera- 1 cells. In BEAS$2 \mathrm{~B}$ cells, p38 was only activated by $\mathrm{Cr}(\mathrm{VI})$. However, the high basal level of $\mathrm{p}-\mathrm{p} 53^{\mathrm{S} 392}$ in BEAS-2B cells, which was not induced by the genotoxic agents, was not affected by p38 inhibition. HeLa cells treated with $500 \mathrm{mM} \mathrm{NaCl}$ were used here as a positive control for p38 activation (lanes 911). These data indicate that $\mathrm{p} 38$ is unlikely the kinase that phosphorylated $\mathrm{p} 53^{\mathrm{S} 392}$ in these cells before and after exposure to these genotoxic agents.

To determine whether CK2 was responsible for $\mathrm{p} 53^{\mathrm{S} 392}$ phosphorylation, we first treated cell with $\mathrm{LiCl}$, which significantly inhibits CK2 [24]. As shown in Figure 6 (lanes $1-8$, right panels), $\mathrm{LiCl}$ treatment led to increased levels of $\mathrm{p} 53^{\mathrm{S} 392}$ phosphorylation with or without treatment with genotoxic agents in iPS cells. In contrast, $\mathrm{LiCl}$ had a limited effect on $\mathrm{p} 53^{\mathrm{S} 392}$ phosphorylation in Tera-1 cells. The high basal level of p-p53 $3^{\mathrm{S} 392}$ in BEAS-2B cells was not affected by $\mathrm{LiCl}$ treatment either. Since the elevated p-p53 ${ }^{\mathrm{S} 392}$ level induced by $\mathrm{LiCl}$ in iPS cells appears to correlate with the increased level of total p53, we normalized the level of total $\mathrm{p} 53$ to see if the difference in the $\mathrm{p}-\mathrm{p} 53^{\mathrm{S} 392}$ level still exists. As shown in Figure 6B, the elevated p-p53 ${ }^{\mathrm{S} 392}$ level remains after normalization of total p53 among treatments, indicating that $\mathrm{LiCl}$ indeed promotes the phosphorylation of $\mathrm{p} 53^{\mathrm{S} 392}$ in iPS cells.

We next treated cells with 4,5,6,7-tetrabromobenzimidazole (abbreviated as TBBz), a specific inhibitor of CK2 [25], to determine whether phosphorylation of $\mathrm{p} 53^{\mathrm{S} 392}$ is at least partly mediated by CK2 in iPS cells. As shown in Figure $6 \mathrm{C}, \mathrm{TBBz}$ treatment significantly enhanced phosphorylation of $\mathrm{p} 53^{\mathrm{S} 392}$ in iPS cells, which is similar to the effect observed after $\mathrm{LiCl}$ treatment in these 

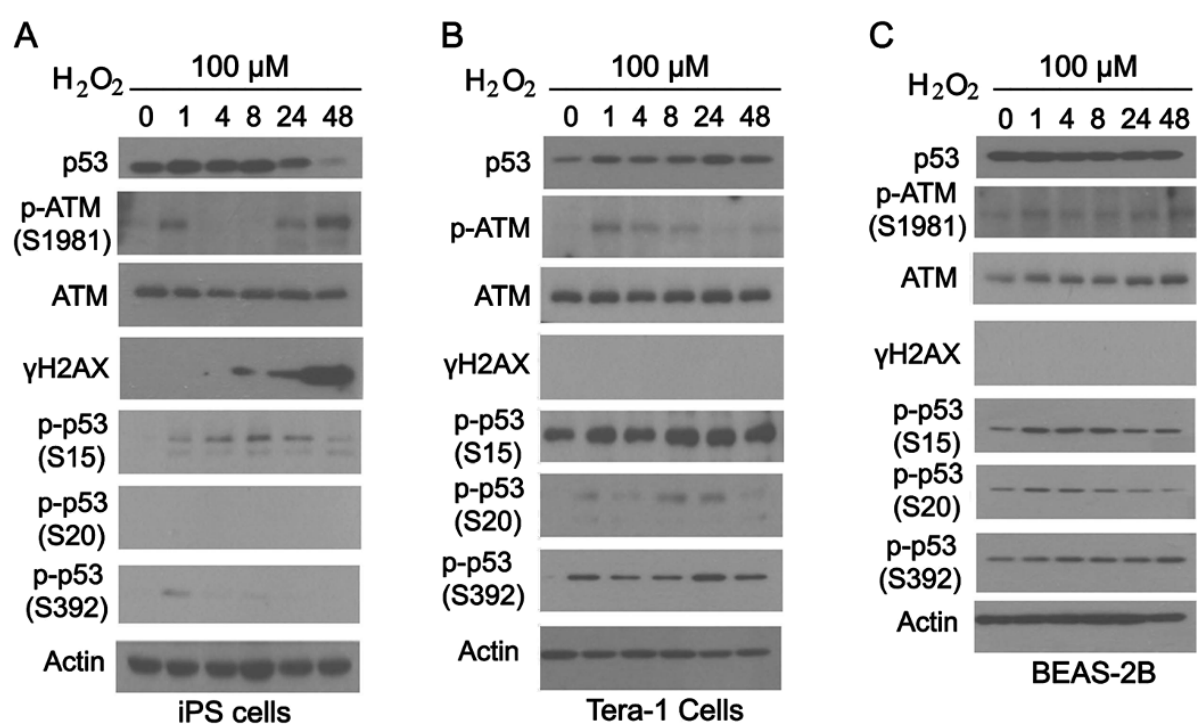

Figure 4 Time-dependent responses of human iPS, Tera-1, and BEAS2B cells to $\mathrm{H}_{2} \mathrm{O}_{2}$. (A) Human iPS cells were cultured under the feederfree condition as described in Experimental procedures and treated with $100 \mu \mathrm{M} \mathrm{H}_{2} \mathrm{O}_{2}$ for the indicated time periods (h). The whole cell lysates were collected and equal amounts of lysates were blotted with antibodies to various cellular components as indicated. (B) Tera- 1 cells were treated and analyzed as described in A. (C) BEAS-2B cells were treated and analyzed as described in $\mathbf{A}$

cells. Combined, these results strongly suggest that CK2 inhibition promotes phosphorylation of $\mathrm{p} 53^{\mathrm{S} 392}$ in iPS cells before and after exposure to genotoxic agents.

\section{Discussion}

The current study surveys the activation of several key elements of DNA damage response pathways in human iPS, Tera- 1 cells, and BEAS-2B cells after treatment with $\mathrm{Cr}$ (VI), a well documented genotoxic agent. We also compared the responses of those cells to other DNA damaging agents including $\mathrm{H}_{2} \mathrm{O}_{2}$ and Dox. Our results indicate that iPS cells possess a rather distinct pattern of responses compared with established cell lines. While $\mathrm{Cr}(\mathrm{VI})$ induces ATM phosphorylation in a unique biphasic fashion and increases the level of $\gamma \mathrm{H} 2 \mathrm{AX}$ after prolonged treatments in iPS cells it is largely unable to elicit phosphorylation of p53 on S15, S20, and S392 in these cells (Figure 3A and Table 1). In contrast, the level of $\mathrm{p}-\mathrm{p} 53^{\mathrm{S} 15}$ is easily inducible by $\mathrm{H}_{2} \mathrm{O}_{2}$ and Dox and $\mathrm{p} 53^{\mathrm{S} 392}$ is strongly induced by Dox in iPS cells (Figures 4A, and $5 \mathrm{~A}$ ). The $\mathrm{p}-\mathrm{p} 53^{\mathrm{S} 20}$ level
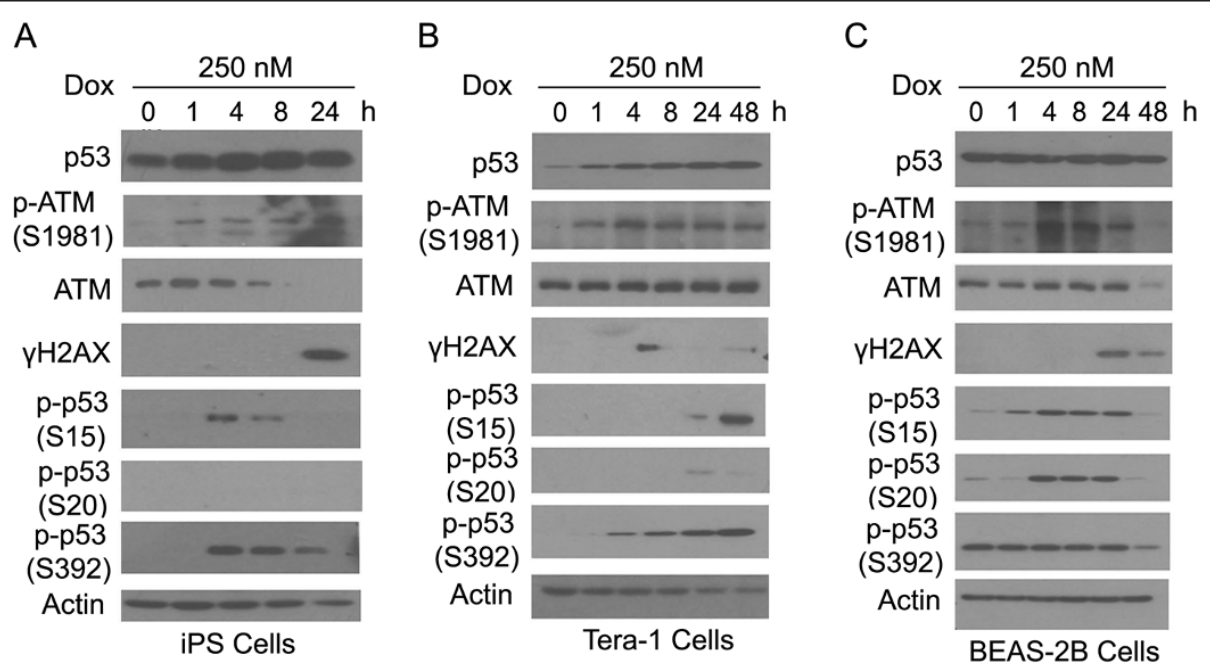

Figure 5 Time-dependent responses of iPS, Tera-1, and BEAS2B cells to Doxorubicin. (A) Human iPS cells were cultured under the feederfree condition as described in Experimental procedures and treated with $250 \mathrm{nM}$ Dox for the indicated times. Whole cell lysates were collected and equal amounts of lysates were blotted with various antibodies as indicated. (B) Tera-1 cells were treated and analyzed as described in $\mathbf{A}$. (C) BEAS-2B cells were treated and analyzed as described in $\mathbf{A}$. 
Table 1 Time-dependent responses of human iPS, Tera-1, and BEAS-2B cells after treatment with $\mathrm{Cr}(\mathrm{VI}), \mathrm{H}_{2} \mathrm{O}_{2}$, or Dox

\begin{tabular}{|c|c|c|c|c|c|c|c|}
\hline Cell type & Treatment & Total p53 & p-ATM & $\mathrm{pH} 2 \mathrm{AX}$ & $p-p 53^{s 15}$ & $p-p 53^{S 20}$ & $p-p 53^{\mathrm{S392}}$ \\
\hline \multirow{6}{*}{ iPS cells } & $\operatorname{Cr}(\mathrm{VI})$ & \multirow{2}{*}{ Up early down late } & \multirow{2}{*}{ Biphasic induction } & \multirow{2}{*}{ Strongly up late } & \multirow{2}{*}{ Unchanged } & \multirow{2}{*}{ Undetectable } & \multirow{2}{*}{ Undetectable } \\
\hline & $10 \mu \mathrm{M}$ & & & & & & \\
\hline & $\overline{\mathrm{H}_{2} \mathrm{O}_{2}}$ & \multirow[t]{2}{*}{ Slightly up early and down late } & \multirow[t]{2}{*}{ Biphasic induction } & \multirow[t]{2}{*}{ Strongly up late } & \multirow{2}{*}{$\begin{array}{l}\text { Strongly up early } \\
\text { and down late }\end{array}$} & \multirow[t]{2}{*}{ Undetectable } & \multirow[t]{2}{*}{ Slightly up early and down late } \\
\hline & $100 \mu \mathrm{M}$ & & & & & & \\
\hline & Dox & \multirow[t]{2}{*}{ Slightly up over time } & \multirow[t]{2}{*}{ Up over time } & \multirow[t]{2}{*}{ Up late } & \multirow{2}{*}{$\begin{array}{l}\text { Up early and } \\
\text { down late }\end{array}$} & \multirow[t]{2}{*}{ Undetectable } & \multirow[t]{2}{*}{ Strongly up early and down late } \\
\hline & $250 \mathrm{nM}$ & & & & & & \\
\hline \multirow{6}{*}{ Tera-1 } & $\operatorname{Cr}(\mathrm{VI})$ & \multirow{2}{*}{ Slightly up over time } & \multirow{2}{*}{ Up late } & \multirow{2}{*}{ Strongly up late } & \multirow{2}{*}{ Strongly up overtime } & \multirow{2}{*}{ Undetectable } & \multirow{2}{*}{ Strongly up over time } \\
\hline & $10 \mu \mathrm{M}$ & & & & & & \\
\hline & $\mathrm{H}_{2} \mathrm{O}_{2}$ & \multirow[t]{2}{*}{ Slightly up over time } & \multirow[t]{2}{*}{ Up early and down late } & \multirow[t]{2}{*}{ Undetectable } & \multirow[t]{2}{*}{ Unchanged } & \multirow{2}{*}{$\begin{array}{l}\text { Up over time and } \\
\text { down late }\end{array}$} & \multirow[t]{2}{*}{ Up early and stays up } \\
\hline & $100 \mu \mathrm{M}$ & & & & & & \\
\hline & Dox & \multirow[t]{2}{*}{ Significantly up over time } & \multirow{2}{*}{$\begin{array}{l}\text { Significantly up early } \\
\text { and down late }\end{array}$} & \multirow{2}{*}{$\begin{array}{l}\text { Strongly up at } 8 \mathrm{~h} \\
\text { and down late }\end{array}$} & \multirow[t]{2}{*}{ Strongly up late } & Slightly up late & Strongly up over time \\
\hline & $250 \mathrm{nM}$ & & & & & & \\
\hline & $\operatorname{Cr}(\mathrm{VI})$ & & & & & & \\
\hline & $10 \mu \mathrm{M}$ & Unchanged & Slightly up over time & Strongly up late & Up over time & Up over time & Unchanged \\
\hline REASE-2R & $\mathrm{H}_{2} \mathrm{O}_{2}$ & Unchanged & Largely unchanged & Undetectable & Largely unchanged & Largely unchanged & Largely unchanged \\
\hline DLAJL-ZD & $100 \mu \mathrm{M}$ & & & & & & \\
\hline & Dox & Unchanged & Up early and down late & Strongly up late & Strongly up early and & Strongly up early & Unchanged up to $24 \mathrm{~h}$ \\
\hline & $250 \mathrm{nM}$ & & & & & & \\
\hline
\end{tabular}


A

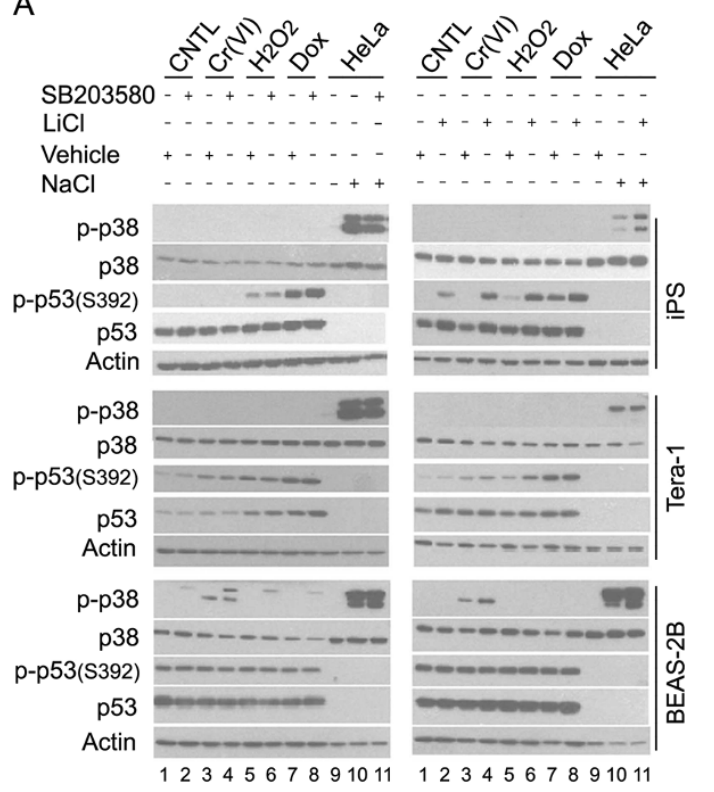

B

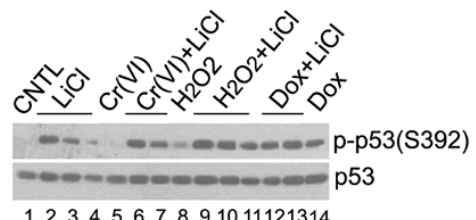

C

$\operatorname{Cr}(\mathrm{VI}) \ldots++\ldots \ldots+\ldots$.

$\mathrm{H}_{2} \mathrm{O} 2 \ldots+\ldots+\ldots+\ldots++.+$

Dox …+ + . . . + +

TBBz $\ldots+\ldots+\ldots+\ldots+\cdots+$

$\mathrm{P}-\mathrm{p5} 53$
$\mathrm{P} 392)$
$\mathrm{p} 53$

Actin

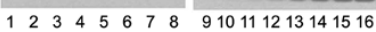

iPS Cells BEAS-2B

Figure 6 Roles of $\mathbf{p} 38$ and CK2 on p53 ${ }^{\mathrm{S392}}$ phosphorylation. (A) Human iPS, Tera-1, or BEAS-2B cells were treated with $10 \mu \mathrm{M}$ Cr(VI), $100 \mu \mathrm{M}$ $\mathrm{H}_{2} \mathrm{O}_{2}$, or $250 \mathrm{nM}$ Dox for $4 \mathrm{~h}$ with or without pretreatment with $10 \mu \mathrm{M}$ SB203580 or $10 \mu \mathrm{M}$ LiCl for one h. HeLa cells treated with $500 \mathrm{mM}$ NaCl was used as a positive control for p38 activation. Whole cell lysates were collected and equal amounts of cell lysates were blotted with antibodies to various molecular components as indicated. (B). Different amounts of human iPS cell lysates from experiments described in (A) were used for Western blot to

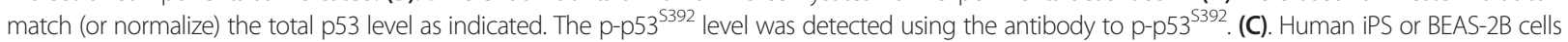
were treated with $10 \mu \mathrm{M} \mathrm{Cr}(\mathrm{V})$ ), $100 \mu \mathrm{M} \mathrm{H}_{2} \mathrm{O}_{2}$, or $250 \mathrm{nM}$ Dox for $4 \mathrm{~h}$ with or without pretreatment with $10 \mu \mathrm{M} \mathrm{TBBz}$ for one h. The whole cell lysates were collected and equal amounts of cell lysates were blotted with antibodies to various molecular components as indicated.

in iPS cells seems to be rather resistant to genotoxic insults as it fails to respond to any of genotoxic agents under study. Compared with iPS cells, p53 phosphorylation patterns on these residues in Tera-1 and BEAS-2B cells are rather different after $\mathrm{Cr}(\mathrm{VI})$ treatment. A gross comparison of the responses of three cell types to these different categories of genotoxic agents reveals some interesting findings: (i) While $\mathrm{p}-\mathrm{p} 53^{\mathrm{S} 20}$ is easily inducible by all three agents in BEAS-2B cells it is much less responsive, if at all, in iPS cells and Tera-1 cells; (ii) Although the level of pp53 $3^{\mathrm{S} 392}$ in BEAS-2B cells is constitutively elevated it is irresponsive to these genotoxic compounds. On the other hand, its phosphorylation is elicited in iPS cells and strongly induced in Tera- 1 cells by these compounds.

Phosphorylation of p53 on S15 is known to stabilize the transcription factor $[15,16]$. Extensive research in the past has shown that this residue is the target of multiple kinases, including ATM and ATR $[15,16]$ whereas S20 is the target of MAPKAPK2, JNK, CHK2 and Plk3 $[15,16]$. Consistent with these studies, we also show that ATM is phosphorylation on S1981 after treatment with various genotoxic agents, correlating with $\mathrm{p} 53$ and $\gamma \mathrm{H} 2 \mathrm{AX}$ phosphorylation. Phosphorylation of p53 on S15 and S20 is believed to an integral part of the DNA damage response in vivo $[15,16]$. The relative resistance of S20 phosphorylation to DNA damaging agents under study in iPS and Tera- 1 cells is intriguing as both types of cells possess stem cell-like characteristics (Figures 1 and 2) $[1,26]$. It is tempting to speculate that stem cells may be lack of components that lead to p53 phosphorylation on S20 or that highly activated p53 may not be ideal for stem cell self-renewal. Supporting this notion, p53 levels adversely affect reprogramming iPS cells from somatic cells [27].

It has been shown that phosphorylation of p53 on S392 is mediated by p38, CK2, PKR, and CDK9 [22,28-30] although a recent study suggests that this residue is not a target of p38 or CK2 but rather of a yet unknown kinase [23]. Moreover, phosphorylation of this residue appears to respond to diverse stimuli that induce p53 [23], suggesting that S392 phosphorylation may play a broad role in the regulation $\mathrm{p} 53$. We have observed that $\mathrm{p}-\mathrm{p} 53^{\mathrm{S} 392}$ signals display rather distinctive profiles in three cell types tested. Notably, p-p53 ${ }^{\mathrm{S} 392}$ levels are very low in iPS and Tera-1 cells. While $\mathrm{p}-\mathrm{p} 53^{\mathrm{S} 392}$ in Tera- 1 cells is highly induced by all three genotoxic agents it is only significantly induced by Dox treatment in iPS cells. On the other hand, p-p53 ${ }^{\mathrm{S} 392}$ levels are high and hardly respond to any type of stimuli under study. These dramatic differences of $\mathrm{p}-\mathrm{p} 53^{\mathrm{S} 392}$ between these cells reflect a complex regulation of this residue in a cell type-dependent and/or stimulus-dependent fashion. Our study with specific chemical inhibitors 
revealed that p38 is not involved in $\mathrm{p} 53^{\mathrm{S} 392}$ phosphorylation in all three cell types with or without genotoxic insults (Figure 6A). CK2 also seems to be not involved in p5 $3^{\mathrm{S} 392}$ phosphorylation in Tera- 1 and BEAS-2B cells either (Figure 6). These results are largely in agreement with the previous study [23]. Surprisingly, CK2 appears to inhibit $\mathrm{p} 53^{\mathrm{S} 392}$ phosphorylation in iPS cells as inhibition of the enzyme strongly enhances p-p $53^{\mathrm{S} 392}$ signals (Figure 6). This observation is very interesting as previous studies show that CK2 can promote, rather than inhibit, p53 phosphorylation on S392 [31]. Therefore, further investigation on how CK2 inhibits p53 ${ }^{\mathrm{S} 392}$ may help to unravel a novel mechanism of p53 regulation in stem cells after exposure to genotoxic stress. Of note, in all the three cell types studied, $\mathrm{p} 53^{\mathrm{S} 392}$ phosphorylation is very closely and positively correlated with the total p53 level (Figure 6A). Given that small molecules have been developed for enhancing p53 activity for the treatment of various cancers [32], our further study of differential responses in stem cells and somatic cells can lead to the discovery of new targets for p53 activation.

The main mechanism of $\mathrm{Cr}(\mathrm{VI})$-mediated DNA damage responses is believed to be through the generation of oxidative stress [6-9]. $\mathrm{H}_{2} \mathrm{O}_{2}$ can directly produce oxidative stresses. Dox inhibits the action of topoisomerase II and also generates oxidative stress, thereby triggering DNA damage response $[19,20]$. Despite the overlapping mechanisms of action of these genotoxic agents, differential responses as revealed by the current study suggest that each agent may activate different signaling components of the DNA damage response network. Thus, the effect of $\mathrm{Cr}(\mathrm{VI})$ on cellular responses may not be just limited to the generation of oxidative stresses. Whether the unique chromatin structures in iPS cells (stem cells) may contribute to the differential responses remains to be determined.

\section{Competing interest}

The authors declare that they have no competing interests.

\section{Authors' contributions}

YL: She carried out experiments and analyzed data. DX: He designed experiments, analyzed data and was involved in manuscript writing. JZ: She was involved in designing and performing experiments. YM: He helped experimenta designs and provided some key reagents. YJ: He helped in data interpretations and provided key reagents. WZ: He helped in experimental designs and data interpretation. WD: He designed experiments, analyzed data, and write the manuscript. All authors read and approved the final manuscript.

\section{Acknowledgement}

This study was supported in part by US Public Service Awards to WD (CA090658 and ES019929), to DX (ES019929), an NIEHS Center grant (ES000260), and a key State project of China on iPS and stem cell research (2011ZX09102-010-04).

\section{Author details}

${ }^{1}$ College of Animal Science and Technology, Northwest A\&F University, Yangling, Shaanxi, China. ${ }^{2}$ Department of Environmental Medicine \& Pharmacology, New York University Langone Medical Center, 57 Old Forge Road, Tuxedo, NY, USA. ${ }^{3}$ Department of Pathology, The State University of
New York, Stony Brook, USA. ${ }^{4}$ Biopharmaceutical Research Center, Chinese Academy of Medical Sciences \& Peking Union Medical College, Suzhou, China.

Received: 22 August 2013 Accepted: 9 September 2013

Published: 20 September 2013

\section{References}

1. Takahashi K, Tanabe K, Ohnuki M, Narita M, Ichisaka T, Tomoda K, et al: Induction of pluripotent stem cells from adult human fibroblasts by defined factors. Cell 2007, 131(5):861-872.

2. Robinton DA, Daley GQ: The promise of induced pluripotent stem cells in research and therapy. Nature 2012, 481(7381):295-305.

3. Kondo T, Asai M, Tsukita K, Kutoku Y, Ohsawa Y, Sunada Y, et al: Modeling Alzheimer's disease with iPSCs reveals stress phenotypes associated with intracellular abeta and differential drug responsiveness. Cell Stem Cell 2013, 12(4):487-496.

4. Xu D, TM O, Shartava A, Fowles TC, Yang J, Fink LM, et al: Isolation, characterization, and in vitro propagation of infantile hemangioma stem cells and an in vivo mouse model. J Hematol Oncol 2011, 4:54.

5. Yang J, Aguila JR, Alipio Z, Lai R, Fink LM, Ma Y: Enhanced self-renewal of hematopoietic stem/progenitor cells mediated by the stem cell gene Sall4. J Hematol Oncol 2011, 4:38.

6. Shi X, Mao Y, Knapton AD, Ding M, Rojanasakul Y, Gannett PM, et al: Reaction of $\mathrm{Cr}(\mathrm{VI})$ with ascorbate and hydrogen peroxide generates hydroxyl radicals and causes DNA damage: role of a $\mathrm{Cr}(\mathrm{IV})$-mediated Fenton-like reaction. Carcinogenesis 1994, 15(11):2475-2478.

7. Chiu A, Katz AJ, Beaubier J, Chiu N, Shi X: Genetic and cellular mechanisms in chromium and nickel carcinogenesis considering epidemiologic findings. Mol Cell Biochem 2004, 255(1-2):181-194.

8. Ding M, Shi X: Molecular mechanisms of $\mathrm{Cr}(\mathrm{VI})$-induced carcinogenesis. Mol Cell Biochem 2002, 234-235(1-2):293-300.

9. Langard S: One hundred years of chromium and cancer: a review of epidemiological evidence and selected case reports. Am J Ind Med 1990, 17(2):189-215

10. Chen L, Ovesen JL, Puga A, Xia Y: Distinct contributions of JNK and p38 to chromium cytotoxicity and inhibition of murine embryonic stem cell differentiation. Environ Health Perspect 2009, 117(7):1124-1130.

11. Momcilovic O, Knobloch L, Fornsaglio J, Varum S, Easley C, Schatten G: DNA damage responses in human induced pluripotent stem cells and embryonic stem cells. PLoS One 2010, 5(10):e13410.

12. Su TT: Cellular responses to DNA damage: one signal, multiple choices. Annu Rev Genet 2006, 40:187-208.

13. Meek DW: Tumour suppression by p53: a role for the DNA damage response? Nat Rev Cancer 2009, 9(10):714-723.

14. Sharma A, Singh K, Almasan A: Histone H2AX phosphorylation: a marker for DNA damage. Methods Mol Biol 2012, 920:613-626.

15. Toledo F, Wahl GM: Regulating the p53 pathway: in vitro hypotheses, in vivo veritas. Nat Rev Cancer 2006, 6(12):909-923.

16. Kruse JP, Gu W: Modes of p53 regulation. Cell 2009, 137(4):609-622.

17. Lee $\mathrm{JH}$, Paull $\mathrm{T}$ : Activation and regulation of ATM kinase activity in response to DNA double-strand breaks. Oncogene 2007, 26(56):7741-7748.

18. Takayama N, Nishikii H, Usui J, Tsukui H, Sawaguchi A, Hiroyama T, et al: Generation of functional platelets from human embryonic stem cells in vitro via ES-sacs, VEGF-promoted structures that concentrate hematopoietic progenitors. Blood 2008, 111(11):5298-5306.

19. Momparler RL, Karon M, Siegel SE, Avila F: Effect of adriamycin on DNA, RNA, and protein synthesis in cell-free systems and intact cells. Cancer Res 1976, 36(8):2891-2895.

20. Gewirtz DA: A critical evaluation of the mechanisms of action proposed for the antitumor effects of the anthracycline antibiotics adriamycin and daunorubicin. Biochem Pharmacol 1999, 57(7):727-741.

21. Keller DM, Lu H: p53 serine 392 phosphorylation increases after UV through induction of the assembly of the CK2.hSPT16.SSRP1 complex. J Biol Chem 2002, 277(51):50206-50213.

22. Huang C, Ma WY, Maxiner A, Sun Y, Dong Z: p38 kinase mediates UV induced phosphorylation of p53 protein at serine 389. J Biol Chem 1999, 274(18):12229-12235.

23. Cox ML, Meek DW: Phosphorylation of serine 392 in p53 is a common and integral event during p 53 induction by diverse stimuli. Cell signal 2010, 22(3):564-571. 
24. Davies SP, Reddy H, Caivano M, Cohen P: Specificity and mechanism of action of some commonly used protein kinase inhibitors. Biochem J 2000, 351(Pt 1):95-105.

25. Sarno S, de Moliner E, Ruzzene M, Pagano MA, Battistutta R, Bain J, et al: Biochemical and three-dimensional-structural study of the specific inhibition of protein kinase CK2 by [5-oxo-5,6-dihydroindolo-(1,2-a) quinazolin-7-yl]acetic acid (IQA). Biochem J 2003, 374(Pt 3):639-646.

26. Ohm JE, McGarvey KM, Yu X, Cheng L, Schuebel KE, Cope L, et al: A stem cell-like chromatin pattern may predispose tumor suppressor genes to DNA hypermethylation and heritable silencing. Nat Genet 2007 39(2):237-242

27. Marion RM, Strati K, Li H, Murga M, Blanco R, Ortega S, et al: A p53mediated DNA damage response limits reprogramming to ensure iPS cell genomic integrity. Nature 2009, 460(7259):1149-1153.

28. Radhakrishnan SK, Gartel AL: CDK9 phosphorylates p53 on serine residues 33, 315 and 392. Cell Cycle 2006, 5(5):519-521.

29. Cuddihy AR, Wong AH, Tam NW, Li S, Koromilas AE: The double-stranded RNA activated protein kinase PKR physically associates with the tumor suppressor p53 protein and phosphorylates human p53 on serine 392 in vitro. Oncogene 1999, 18(17):2690-2702.

30. Hupp TR, Meek DW, Midgley CA, Lane DP: Regulation of the specific DNA binding function of p53. Cell 1992, 71(5):875-886.

31. Meek DW, Simon S, Kikkawa U, Eckhart W: The p53 tumour suppressor protein is phosphorylated at serine 389 by casein kinase II. Embo J 1990 9(10):3253-3260

32. Saha MN, Qiu L, Chang $\mathrm{H}$ : Targeting $\mathrm{p} 53$ by small molecules in hematological malignancies. J Hematol Oncol 2013, 6:23.

doi:10.1186/1756-8722-6-71

Cite this article as: Lu et al: Differential responses to genotoxic agents between induced pluripotent stem cells and tumor cell lines. Journal of Hematology \& Oncology 2013 6:71

\section{Submit your next manuscript to BioMed Central and take full advantage of:}

- Convenient online submission

- Thorough peer review

- No space constraints or color figure charges

- Immediate publication on acceptance

- Inclusion in PubMed, CAS, Scopus and Google Scholar

- Research which is freely available for redistribution 